ISSN 0258-7122

Bangladesh J. Agril. Res. 37(2): 271-277, June 2012

\title{
EFFECT OF BAU-BIOFUNGICIDE, NEEM OIL AND A NEMATICIDE ON THE ROOT-KNOT (Meloidogyne javanica) OF PAPAYA (Carica papaya)
}

\author{
M. A. A. PRADHAN ${ }^{1}$, M. M. RAHAMAN ${ }^{2}$, S. K. PAUL ${ }^{3}$ \\ M. U. AHAMAD ${ }^{4}$ AND B. K. GOSWAMI ${ }^{5}$
}

\begin{abstract}
In a pot experiment, BAU-Biofungicide (Trichoderma harzianum) neem oil and curaterr (carbofuran) 5G were tested against root-knot (Meloidogyne javanica) of two papaya varieties Kashempuri and Deshi papaya. Seedlings were inoculated with second stage larvae of $M$. javanica. Neem oil (5 ml/ $10 \mathrm{~g}$ seeds) and BAU-Biofungicide (1:4) were used as seed treatant and curaterr as side dressing. Both the bio-agents significantly increased the root and shoot growth of papaya plant and reduction of galls and eggmasses and suppressed the development of $\mathrm{J}_{2}, \mathrm{~J}_{3}$, and $\mathrm{J}_{4}$ and adult females of $M$. javanica. Efficacy of BAU-Biofungicide was to reduce the gall and nematode development and to increase plant growth was similar to nematicide curaterr. BAU-Biofungicide gave higher effect in most of the growth characters compared to neem oil and prevented the development of adult females and juveniles like nematicide curaterr.
\end{abstract}

Keywords: Papaya, root-knot, BAU-Biofungicide, neem oil, curaterr.

\section{Introduction}

Papaya (Carica papaya) is one of the most versatile fruits. It is also used as vegetable and available throughout the year in Bangladesh. The production of papaya in the country is not up to the mark due to the incidence of various diseases. Among those diseases, root-knot (Meloidogyne spp.) plays an important role against its successful cultivation (Page, 1979).

When populations of the plant parasitic nematodes reach the economic threshold levels that can cause considerable mechanical or physiological root damages which inhibit the growth and prevent the uptake of water and nutrients. As a result, yield is greatly affected (Mian, 1986). The common species of rootknot nematodes in Bangladesh are $M$. incognita and $M$. javanica which attack wide variety of field crops, vegetables, and fruit crops including papaya (Timm and Ameen, 1960; Mian, 1986). Meloidogyne javanica and M. incognita are important nematode species in Bangladesh (Page, 1979; Mian, 1986). As a result, enormous crop loss is incurred every year in Bangladesh. In order to control this

${ }^{1}$ Former research student, ${ }^{4}$ Professor, Plant Pathology Division, Bangladesh Agricultural University (BAU), Mymensingh, ${ }^{3}$ Research student, Iwate University, Japan, ${ }^{2}$ Scientific Officer and ${ }^{5}$ Principal Scientific Officer, Plant Pathology Division, RARS, BARI, Jamalpur, Bangladesh. 
disease, farmers are advised to use synthetic nematicides. But biological control of pathogens offers environmentally safe, durable and cost effective alternatives to chemicals (Papavizas and Lumsden, 1980). Trichoderma spp. are antagonists to plant pathogenic nematodes which have also been found to stimulate the growth of the plant (Inber et al., 1994). Trichoderma harzianum showed better control of Meloydogyne javanica on tomato (Yang-XiuJuan et al., 2000). Trichoderma harzianum improved growth (leaves) and root of $M$. javanica infected plants and decreased the root galling index (adult 57\%) and the number of eggmasses/g of root in tomato plant (Manuzca, 2001). Other than chemical agents, various organic amendments like neem and mustard oil cakes have been reported to show high nematicidal activity ( Hossain, 2003). Carbofuran in different trade names is recommended to control nematodes (Vyas and Patel, 2001). Although, papaya is important in Bangladesh, little attention has been given for controlling the nemic disease through biological means. The present investigation was undertaken to test comparative efficacy of BAU-Biofungicide, neem oil and a nematicide curaterr to control root-knot of papaya.

\section{Materials and Method}

BAU-Biofungicide is Trichoderma harzianum based organic matters effective against fungal pathogens. Curatter 5G is a carbofuran based granular pesticides. BAU-Biofungicide and neem oil were used as seed treatants before sowing. Curatter 5G was applied as side dressing. The experiment was conducted in the glasshouse of the Seed Pathology Center, Bangladesh Agricultural University, Mymensingh, Bangladesh.

The pot soil was prepared by mixing sandy loam soil, fresh sand and welldecomposed cowdung@2:1:1 ratio. After thorough mixing, the pot soil was sterilized with formalin @ $30 \mathrm{ml} / 1000 \mathrm{ml}$ water for each cubic feet soil. Forty earthen pots of $30 \mathrm{~cm}$ diameter were taken and each was filled with $5 \mathrm{~kg}$ sterilized dried soil. Healthy and mature seeds of variety Kashempuri and Deshi papaya were treated with $1 \%$ chlorox for 2 minutes and then washed thrice in sterilized water. Seeds of two varieties were treated with BAU-Biofungicide @ 1:40 w/w following the method of Biswas and Sen (2000). In separate petridishes seeds were treated with neem oil @ 5ml/10g seed (Guzman and Saxena, 1997). After coating, seeds were placed in a cool and dry place under shade for drying and were directly sown in the pots on the same day. One plant/pot was allowed to grow within the glasshouse providing necessary irrigation, loosening the soil, and weeding.

After 15 days of sowing, each papaya plant was inoculated with eight eggmasses of $M$. javanica collected from infected brinjal plant. The eggmasses were placed around the base of the seedlings over exposed roots. BAU- 
Biofungicide and granular curaterr (Carbofuran) was applied as side-dressing @ $200 \mathrm{mg}$ and $500 \mathrm{mg} /$ plant, respectively, around the root region of seedlings after 10 days of inoculation with eggmasses.

Four treatments viz., seed treatment with BAU-Biofungicide, seed treatment with neem oil, side dressing with nematicide Curaterr and control were used in the experiment and each was replicated five times (pots). The pots were arranged on the floor of the nethouse following randomized complete block design with two varieties. Seventy five days after inoculation, the plants were removed from pots and root systems were washed with running tap water and data on length (cm) and fresh weight (g) of roots and shoots, number of galls per root system and number of eggmasses per nodules. Populations of $\mathrm{J}_{2}, \mathrm{~J}_{3}, \mathrm{~J}_{4}$, and adult female per $10 \mathrm{~g}$ galls of each plant were also recorded. Data were analyzed statistically following MSTAT-C programme.

\section{Results and Discussion}

\section{Plant growth}

Seed treatment with BAU-Biofungicide and neem oil, and side dressing of curaterr resulted significant increase in length and fresh weight of shoot and root of papaya over control. The highest increase in both shoot and root growth was achieved with curaterr followed by BAU-Biofungicide and neem oil (Table 1).

The maximum of 28.3 galls per root system and 49.5 egg masses per 10 galls were found under control. All the treatments significantly reduced both number of galls and egg masses over control. Gall number was reduced to 1.70, 3.60, and 7.10 per root system, and egg masses per 10 galls was reduced to 10.9, 15.8, and 30.1 due to treatments with BAU-Biofungicide, neem oil and curaterr, respectively (Table 1 ).

Table 1: Effect of different treatments on the growth, galling and eggmass development in papaya infected with $M$. javanica.

\begin{tabular}{l|c|c|c|c|l|c}
\hline Treatments & $\begin{array}{c}\text { Length of } \\
\text { shoot } \\
(\mathrm{cm})\end{array}$ & $\begin{array}{c}\text { Length of } \\
\text { root }(\mathrm{cm})\end{array}$ & $\begin{array}{c}\text { Fresh wt } \\
\text { of shoot } \\
(\mathrm{g})\end{array}$ & $\begin{array}{c}\text { Fresh wt } \\
\text { of root } \\
\text { (g) }\end{array}$ & $\begin{array}{c}\text { No. of galls/ } \\
\text { root system }\end{array}$ & $\begin{array}{c}\text { No. of } \\
\text { eggmasses/10 } \\
\text { galls }\end{array}$ \\
\hline Control & $31.6 \mathrm{~d}$ & $19.8 \mathrm{~d}$ & $28.5 \mathrm{~d}$ & $19.5 \mathrm{~d}$ & $28.3 \mathrm{a}$ & $49.5 \mathrm{a}$ \\
$\begin{array}{l}\text { BAU- } \\
\text { Biofungicide }\end{array}$ & $64.5 \mathrm{~b}$ & $41.3 \mathrm{~b}$ & $114.9 \mathrm{~b}$ & $34.6 \mathrm{~b}$ & $3.60 \mathrm{~b}$ & $15.8 \mathrm{~b}$ \\
$\begin{array}{l}\text { Neem oil } \\
\text { Curaterr }\end{array}$ & $51.9 \mathrm{c}$ & $34.6 \mathrm{c}$ & $98.4 \mathrm{c}$ & $29.9 \mathrm{c}$ & $7.10 \mathrm{~b}$ & $30.1 \mathrm{c}$ \\
\hline
\end{tabular}

Each value is an average of five replications and those within a column having a common letter(s) do not differ significantly $(\mathrm{P}=0.05)$ by DMRT 
Table 2. Interaction effects of treatments and varieties of papaya on the growth, galling and eggmasses.

\begin{tabular}{l|c|c|c|c|c|c}
\hline $\begin{array}{c}\text { Treatment } \\
\text { combination }\end{array}$ & $\begin{array}{c}\text { Length of } \\
\text { shoot } \\
(\mathrm{cm})\end{array}$ & $\begin{array}{c}\text { Length of } \\
\text { root }(\mathrm{cm})\end{array}$ & $\begin{array}{c}\text { Fresh wt } \\
\text { of shoot } \\
(\mathrm{g})\end{array}$ & $\begin{array}{c}\text { Fresh wt } \\
\text { of root } \\
(\mathrm{g})\end{array}$ & $\begin{array}{c}\text { No. of } \\
\text { galls/plant } \\
\text { root system }\end{array}$ & $\begin{array}{c}\text { No. of } \\
\text { eggmasses/10 } \\
\text { galls }\end{array}$ \\
\hline $\mathrm{T}_{0} \times \mathrm{V}_{1}$ & 30.44 & 20.11 & 25.84 & 19.69 & 30.60 & 49.00 \\
$\mathrm{~T}_{0} \times \mathrm{V}_{2}$ & 32.86 & 19.86 & 31.25 & 19.38 & 26.00 & 50.00 \\
$\mathrm{~T}_{1} \times \mathrm{V}_{1}$ & 61.47 & 41.16 & 106.44 & 34.48 & 3.40 & 15.80 \\
$\mathrm{~T}_{1} \times \mathrm{V}_{2}$ & 67.60 & 41.03 & 123.51 & 34.73 & 3.80 & 15.80 \\
$\mathrm{~T}_{2} \times \mathrm{V}_{1}$ & 50.68 & 34.72 & 93.47 & 29.90 & 9.20 & 29.80 \\
$\mathrm{~T}_{2} \times \mathrm{V}_{2}$ & 53.14 & 34.57 & 103.40 & 29.89 & 5.00 & 30.40 \\
$\mathrm{~T}_{3} \times \mathrm{V}_{1}$ & 76.22 & 55.69 & 157.81 & 53.45 & 3.00 & 11.00 \\
$\mathrm{~T}_{3} \times \mathrm{V}_{2}$ & 85.04 & 55.88 & 165.46 & 54.04 & 0.40 & 10.80 \\
\hline
\end{tabular}

Each value is an average of five replications; $\mathrm{T}_{0}=$ Control, $\mathrm{T}_{1}=$ BAU-Biofungicide, $\mathrm{T}_{2}=$ Neem oil, and $\mathrm{T}_{3}=$ Curaterr and $\mathrm{V}_{1}=$ Kashempuri, $\mathrm{V}_{2}=$ Deshi variety.

\section{Nematode development}

Significant reduction in population of $\mathrm{J}_{2}, \mathrm{~J}_{3}, \mathrm{~J}_{4}$ and adult female were achieved with all treatments treated in the experiment. The lowest populations of the nematode under different developmental stages were found under the treatment with curaterr followed by BAU- Biofungicide and neem oil. The efficacy of curaterr and BAU- Biofungicide to reduce nematode populations in roots of papaya was statistically similar and significantly higher compared to neem oil (Table 3).

Table 3. Effect of different treatments on the development of adult females and juveniles of $M$. javanica in papaya.

\begin{tabular}{l|l|l|l|l}
\hline Treatments & $\begin{array}{c}\text { No. of adult } \\
\text { females/ } \\
10 \text { galls }\end{array}$ & $\begin{array}{c}\text { No. of } \mathrm{J}_{2} \\
\text { juveniles/ } \\
10 \text { galls }\end{array}$ & $\begin{array}{c}\text { No. of } \mathrm{J}_{3} \\
\text { juveniles/ } \\
10 \text { galls }\end{array}$ & $\begin{array}{c}\text { No. of } \mathrm{J}_{4} \\
\text { juveniles/ } \\
10 \text { galls }\end{array}$ \\
\hline Control & $8.50 \mathrm{a}$ & $7.20 \mathrm{a}$ & $8.70 \mathrm{a}$ & $6.10 \mathrm{a}$ \\
BAU-Biofungicide & $2.40 \mathrm{c}$ & $2.60 \mathrm{c}$ & $3.00 \mathrm{c}$ & $2.40 \mathrm{~b}$ \\
Neem oil & $3.40 \mathrm{~b}$ & $3.70 \mathrm{~b}$ & $5.40 \mathrm{~b}$ & $2.40 \mathrm{~b}$ \\
Curaterr & $1.60 \mathrm{c}$ & $2.10 \mathrm{c}$ & $3.80 \mathrm{c}$ & $1.60 \mathrm{~b}$ \\
\hline
\end{tabular}

Each value is an average of five replications and those within a column having a common letter(s) do not differ significantly $(\mathrm{P}=0.05)$ by DMRT. 
Table 4. Interaction effects of treatments and varieties of papaya on the development of adult females and juveniles of Meloidogyne javanica.

\begin{tabular}{l|l|l|l|l}
\hline $\begin{array}{c}\text { Treatments } \\
\text { Combination }\end{array}$ & $\begin{array}{c}\text { Number of } \\
\text { adult } \\
\text { females/ } \\
\text { 10 galls }\end{array}$ & $\begin{array}{c}\text { Number of } \mathrm{J}_{2} \\
\text { juveniles/ } \\
10 \text { galls }\end{array}$ & $\begin{array}{c}\text { Number of } \mathrm{J}_{3} \\
\text { juveniles/ } \\
10 \text { galls }\end{array}$ & $\begin{array}{c}\text { Number of } \mathrm{J}_{4} \\
\text { juveniles/ } \\
\text { 10galls }\end{array}$ \\
\hline $\mathrm{T}_{0} \times \mathrm{V}_{1}$ & 8.40 & 7.40 & 8.60 & 6.40 \\
$\mathrm{~T}_{0} \times \mathrm{V}_{2}$ & 8.60 & 7.00 & 8.80 & 5.80 \\
$\mathrm{~T}_{1} \times \mathrm{V}_{1}$ & 2.40 & 2.60 & 3.00 & 2.40 \\
$\mathrm{~T}_{1} \times \mathrm{V}_{2}$ & 2.40 & 2.60 & 3.00 & 2.40 \\
$\mathrm{~T}_{2} \times \mathrm{V}_{1}$ & 3.40 & 3.80 & 5.60 & 2.40 \\
$\mathrm{~T}_{2} \times \mathrm{V}_{2}$ & 3.40 & 3.60 & 5.20 & 2.40 \\
$\mathrm{~T}_{3} \times \mathrm{V}_{1}$ & 1.80 & 2.00 & 3.80 & 1.60 \\
$\mathrm{~T}_{3} \times \mathrm{V}_{2}$ & 1.40 & 2.20 & 3.80 & 1.60 \\
\hline
\end{tabular}

Each value is an average of five replications; $\mathrm{T}_{0}=$ Control, $\mathrm{T}_{1}=$ BAU-Biofungicide, $\mathrm{T}_{2}=$ Neem oil and $\mathrm{T}_{3}=$ Curaterr and $\mathrm{V}_{1}=$ Kashempuri, $\mathrm{V}_{2}=$ Deshi variety.

\section{Response of papaya varieties inoculated with M. javanica}

Shoot length was $54.7 \mathrm{~cm}$ in Papaya variety Kashempuri and 59.60 in variety Deshi. The difference was significant.

Root length, fresh shoot weight, root weight, gall/root system, number of egg masses, $\mathrm{J}_{2}, \mathrm{~J}_{3}, \mathrm{~J}_{4}$ and adult females were $37.9 \mathrm{~cm}, 34.3 \mathrm{~g}$ per plant, 95.8g, 115, 26.7, 4.00, 3-95, 5.25, and 3.20 per 10 galls in variety Kashempuri and $37.8 \mathrm{~cm}$, 105.9g, 34.5g per plant, 8.80, 2.67, 3.95, 3.85, 5.20 and 3.05 per 10 galls, respectively. Their differences were not significant.

Findings of the present investigation reveal that seed treatment with BAUBiofungicide@ 1:4 (w/w), neem oil @ 5 ml/10g papaya seeds, and side dressing with curaterr@ 500 mg/plant are effective to control root-knot disease of Papaya and to increase plant growth. Similar results have also been reported by other investigators.

Poornima and Vadivelu (1990) reported that carbofuran was one of the most effective chemicals in checking development and reproduction of $M$. javanica in the roots of aubergine plant. Khan and Alam (1985) also reported that carbofuran is highly toxic to $M$. incognita and inhibited larval hatching in tomato seedlings.

The effectiveness of BAU- Biofungicide contained Trichoderma spp. may be attributed to the fact that the fungi occupy the niche before nematode infection and thereby hinder the establishment of the plant parasitic nematode pathogen as 
stated by Bettiol, 1996. Similar observations were also made by El-Moity et al., (1998) and Khan et al. (2001).

Guzman and Saxena (1997) showed that neem oil, neem extract, and neem cake had high nematicideal activity against the root-knot nematode ( $M$. incognita) in both laboratory and greenhouse. Reddy et al. (1993) showed that neem oil cake significantly reduced root-knot severity and increased fruit yield of okra compared to control. Nimin, a neem product significantly reduced the rootkont and soil populations of $M$. inognita and increased the plant growth parameters (Mojumder et al., 2004).

It is evident form the study that control of $M$. javaanica with BAUBiofungicide prepared with antagonistic fungus $T$. harzianum and neem oil as seed treating agents are quite effective. Therefore, control of $\mathrm{f}$ root-knot disease of papaya caused by $M$. javanica through the use of BAU-Biofungicide and neem oil may be explored for eco-freindly management of root-knot nematode.

\section{References}

Bettiol, W. 1996. Biological control of plant pathogens in Brazil: Application and Current Research. World J. Microbiol. And Biotech. 12(5):505-510.

Biswas, K. K. and C. Sen. 2000. Management of stem rot of Groundnut caused by Sclerotium rolfsii through Trichoderma harzianum. Indian Phytopathol. 13(3):290295.

El-Moity, T. H. A., E. M. Ali, M.H. El-Hamawi, T. El-Sharkawy and K. Tiilikkala. 1998. Effect of some biological agents on reproduction of Meloidogyne incognita on tomato plants . Egyptian J. Agril. Res. 76(1): 51-62.

Guzman, R. S. and R. C. Saxena. 1997. Nematiciddal activity of neem and its derivatives. J. Res. (Philippines) 4(1-2): 40-44.

Hossain, S.S., 2003. Comparative efficacy of neem and Furadan 5G in controlling rootknot (Meloidogyne javanica) of cotton. M. S. Thesis. Dept. of P. Path. BAU. Mymensingh.

Inber, J., M., D. Abremsky and I. Cohen. 1994. Plant growth enhancement and disease control by $T$. harzianum in vegetable seedlings grown under commercial conditions. European J. Plant Pathol. 1000:337-346.

Khan, A.A., M. Anjum and M.M. Alam. 1985. Control of Meloidogyne incognitsa on tomato by chemical dips. Pakistan J. Nematol. 3(2): 105-109 [ Helminth. Abs. 55(1): 23].

Khan, H. U., Riaz, A. and S. M. Khan 2001. Evaluation of culture filtrates of different fungi on the hatching of Meloidogyne incognita. Pakistan J. Phytopathol. 13(1): 56-60.

Manuzca, G.A., 2001. Identification and evaluation of fungal organism as possible biocontrol agents of Meloydogyne spp. Phytopathologia. Colombiana. 25(1-2): 33-38

Mian, I. H., 1986. Plants parasitic nematodes associated with some crop species in Bangladesh . Bangladesh J. Plant Pathol. 2: 7-13. 
Mojumder,V., Pankj, Gautam-Chawla and Jagwant-Singh. 2004. Division of Nematology, Indian Agricultural Research Institute, New Delhi-110012, India. Indian J. Nematol. 34(1):60-63.

Page, S. L. J., 1979. An assessment of the importance and control of plant parasitic nematodes of vegetable crops in Bangladesh . Imp. College Field Station, Silwood Park., Ascot, Berks; England: 1-36 pp,

Papavizas, G. C. and R. P. Lumsden. 1980. Biological control of soil borne fungal propagules . Ann. Rev. Phytopathol. 18: 389-413.

Poornima, K. and S. Vadivelu. 1990. Comperatiev efficacy of nenaticides, oli-cake and plant extracts in the management of Meloydogyne incognita, Pratylenchus delatireiand, Rotylenchus reniformis on brinjal. Indian J. Nematol. 20(2):170-173. [Nematol. Abst. 64(2):82].

Reddy, P. P., R. M. Khan, M. S. Chari and G. Ramaprasad. 1993. Effect of oil cakes on root-knot nematode and yield of okra. Botanical pesticides in integrated pest management: Proceeding of National Symposium held on January 21-22, 1990 . at Central Tobacco research institute, Rajahmundry, 533 105, Indian. 424-426.

Timm, R. W. and M. Ameen. 1960. Nematodes associated with commercial crops in East Pakistan. Agric. Pak. 11(3): 355-363.

Vyas, R. V. and D. J. Patel. 2001. Management of root-knot nematode in banana. Indian J. Nematol. 31(1): 86-87.

Yang-XiuJuan, He-Yuxian, Chen-Furu and Zhengliang. 2000. Isolation and selection of eggmasses of Meloydogyne spp. Fujian province. in Fujiana. J. Agril. Sci. 15(1): 12-15. 